\title{
Human Resource Management and its Effects on the Performance of Nigerian Commercial Banks
}

\author{
Dr. Cross Ogohi Daniel* \\ Department Of Business Administration, Nile University Of Nigeria, Abuja \\ *Corresponding Author: Dr. Cross Ogohi Daniel, Department Of Business Administration, Nile \\ University of Nigeria, Abuja
}

\begin{abstract}
Human Resources have been identified by many authorities as the most important asset of any organization. This is because they are the users of the rest of the resources in the organization. Indeed, studies have shown that this resource is among the most under-utilized in many organizations. This paper work is mainly concern with the impact of Human Resources Management in Nigerian Commercial Banks in Abuja. The data for this study were purposely collected through the secondary sources and analyzed using content analysis approach. At the end of the study, some observations were made. The study also revealed that target setting and cooperate value ethics are adequate and employees have job satisfaction. The observations from the study necessitated certain recommendation which required total overhaul of the role of the Human Resources department aimed at improving Human Resource Management in the organization.
\end{abstract}

Keywords: Human Resource Management, Performance, Human resource Development and Commercial Banks

\section{INTRODUCTION}

In recent times, the term Human Resource Management, has replaced personnel management to emphasize the fact that people employed in an organization are a resource that should be utilized to full capacity in the same way that financial and material resources are managed to produce the utmost benefit. There are four major resources available to any organization; manpower, money, materials and machinery, commonly referred to as the $4 \mathrm{M}$ 's. Considering these four resources, manpower is the most vital while others are passive resources. The achievement of an organization's goals or objectives will not be possible without manpower.

Thus, human resource is the most important element in any organization. According to Scott, Clothier and Spiegel (1977) ${ }^{[1]}$, the objectives of Human Resource Management, in an organization, is to get maximum individual development, desirable working relationships between employers and employees, employees and employees, and to affect the molding of human resources as compared with physical resources.

Human Resources Development is one of the activities of Human Resource Management with special emphasis on training and development. It is concerned with the framework for the expansion of human capital within an organization. Human Resources Development is a combination of Training and Education that ensures the continual improvement and growth of both the individual and the organization. Financial institutions and indeed many organizations today are increasingly recognizing the importance of developing their human resources. This has become very important following the challenges facing them especially the financial institutions due to hyper-competition, globalization and fast paced technology which have continued to put pressure on creativity, innovations, speed and flexibility. It is this realization that the banks are enhancing the competencies of their personnel by providing them with more and more training and development opportunities, maintaining good interpersonal relationship and also creating an atmosphere of trust and confidence.

\section{Statement of the Problem}

One of the major problems confronting management in any organization is the inability to effectively manage People as to achieve its goals and objectives. It is against this backdrop that this research will 
assess the impact of human resource management on the performance of Commercial banks employees in Nigeria and investigate the impact of human resource practices (recruitment \& selection, training \& development, compensation and performance appraisal) on organization's performanceOne of the major problems confronting management in any organization is the inability to effectively manage people as to achieve its goals and objectives.

It is against this backdrop that this research will assess the impact of human resource management on the performance of Commercial banks employees in Nigeria and investigate the impact of human resource practices (recruitment \& selection, training \& development, compensation and performance appraisal) on organization's performance

\section{OBJECTIVES OF THE STUDY}

The main purpose of the study was to identify the impact of Human Resource Management on performance on Nigerian commercial Banks. In order to materialize this objective, the following specific objectives were considered.

- To determine the impact of target setting, co-operate value and ethics on organizational performance.

- To explore the importance Human Resource practices on employee performance evaluation toward achievement of organization's goals and objective.

\section{LITERATURE REVIEW}

\subsection{Conceptual Framework on Human Resources}

Human Resource Management (HRM) is a relatively new approach to managing people in any organization. People are considered the key resource in this approach. It is concerned with the people dimension in management of an organization. Since an organization is a body of people, their acquisition, development of skills, motivation for higher levels of attainments, as well as ensuring maintenance of their level of commitment are all significant activities.

Scott et al (1997) ${ }^{[1]}$ have defined Human Resource Management as that branch of management which is responsible on a staff basis for concentrating on those aspects of operations which are primarily concerned with the relationship of management to employees and employees to employees and with the development of the individual and the group. Human Resource Management is responsible for maintaining good human relations in the organization. It is also concerned with development of individuals and achieving integration of goals of the organization and those of the individuals.

Northcott $(1991)^{[2]}$ considers human resource management as an extension of general management, that of prompting and stimulating every employee to make his fullest contribution to the purpose of a business. Human resource management is not something that could be separated from the basic managerial function. It is a major component of the broader managerial function.

French $(2006)^{[3]}$ defines Human resource management as the recruitment, selection, development, utilization, compensation and motivation of human resources by the organization. According to Flippo (1984) ${ }^{[4]}$ human resource management is the planning; organizing, directing and controlling of the procurement, development, resources to the end those individual and societal objectives are accomplished. This definition reveals that human resource management is that aspect of management, which deals with the planning, organizing, directing and controlling the personnel functions of the enterprise. Human Resource Management can be described as a strategic, integrated and coherent approach to the employment, development and wellbeing of the people working in organizations. Human resource management is the policies, practices, and systems that influence employees' behavior, attitudes, and performance. Many companies refer to human Resource management as involving.

There are several important human resource management practices that should support the organization's business strategy: analyzing work and designing jobs, determining how many employees with specific knowledge and skills are needed (human resource planning), attracting potential employees (recruiting), choosing employees (selection), teaching employees how to perform their jobs and preparing them for the future (training and development), evaluating their performance (performance management), rewarding employees (compensation), and creating a positive work environment (employee relations). An organization performs best when all of these practices are 
managed well. At organizations with effective human resource management, employees and customers tend to be more satisfied, and the organization tend to be more innovative, have greater productivity, and develop a more favorable reputation in the community (Raymond et al, 2011) ) $^{[5]}$.

Ogundele $(1983)^{[6]}$ asserted that without effective and productive human resources, no objective would be properly executed. He added that we must try not only to retain the employees we recruited but also encourage them at all levels to become useful, effective and productive employees.

According to Osunkunle (2002) ${ }^{[7]}$, there are three basic elements in Human Resource Management in the Banking business or Industry, namely:

- The competence of the people which reflects the training and exposure that the people have and must match the demands of the contemporary market.

- Their values and motivation; values represent what the people place premium on and it therefore, shape their decisions and choices.

- Their attitude which reflects their disposition to customers and thus affects the ability of the bank to retain its

- Customers and achieve significant business growth in the long-term. From the foregoing, it is safe to state that management of people plays a major role in creating a healthy organization and equally sustaining their competitive advantages

\subsection{Target Setting / Corporate Values and Ethics}

The three fundamental issues in corporate values and ethics according to Osunkunle $(2002)^{[7]}$ concerns: Defining or specifying clearly the values of the organization, this presents what commercial bank places premium on and forms the minimum expectation from its employees. It is such specification that sets the rules and code of behavior, the violation which will invite a sanction however subtle.

Arrangement should also be made to reinforce the initial communication such that employees do not regard it as a one-off affair. Getting the staff to buy into it is perhaps the most difficult aspect of the task. This is also why commercial banks are usually advised to get staff involved in designing policies and where this is not feasible; let them appreciate the rational early enough before full implementation. Once a commercial bank gets its employee to buy into its values and they have good understanding of its core values, it becomes easy (relatively) for them to start to bond together.

The essence of a company's identity, long lasting, possibly immutable values and guiding principles by which a company can chart its course across the business areas. These values include integrity, innovations, will power, humility, accountability, loyalty and responsibility to stakeholders. Humans are active agents who accumulate wealth, exploit materials resources, build social economic and political organizations and carry out national development.

Most Nigerian commercial banks have adopted the strategy of target setting for their staff in order to address the twin problems of competitive remuneration and performance management. Usually the target is set throughout the organization and rewards for performance are attached to encourage the right behavior by staff. Targets are issued to staff and threat to job security imposed for those who fall short of their targets over a period of time.

The desperation that this creates makes the staff of such banks engage in all sort of unprofessional and unethical practices in the dictum of "the end justifies the means". Invariably, the banks image suffers and it's rubs-off on the entire industry. However, it may not be wise to say that target setting is bad because all private sector organization including banks have to be performance and target driven to keep their stakeholders happy by encouraging good returns on investment.

\subsection{Employees Performance Evaluation}

Every organization business, society, social, political or religious functions principally to achieve set targets attains set goals or meet set objectives. These objectives may range from capturing sizeable market share and profit maximization for business organization, through enlarging party membership and saving souls for spiritual or religious organization.

Irrespective of its goals or objective, every organization needs skillful and systematic combination of human and material resources to translate these goals into reality, whereas the materials can easily be assessed and evaluated, human Resource which is the most vital asset of an organization cannot be 
plainly and easily evaluated. This is born out of fact that humans are dynamic, rational and react differently to the same work and social situation based on their needs and on their socio-cultural values. As employees carry out their job roles, they must have a firm knowledge on how well they are performing their present job, their potentials for improvement on performance and their potential for higher levels of responsibility. It is the function of management in consultation with employees to develop performance evaluation system which will help employees meet their development needs and also provide management with an informed and fair basis for decisions about salary advancement, training and promotion, dismissal, transfer and other treatment of employees.

For any business organization to function effectively, it must have thorough knowledge of the abilities, capacities and potentials of its human resources. This will enable the organization to know the areas of strength and weakness of its personnel and also to determine its objectives and goals and potentials of the available work force, this principally is the whole essence of performance evaluation. Armstrong (1982 ${ }^{[8]}$ posited: Performance appraisal is the process of reviewing an individual's performance and progress in a job, and assessing his potentials for future promotion.

Performance evaluation is thus a systematic process aimed at enhancing organizational growth and development by systematically collecting and interpreting information about an individual with a view to improving his overall performance and ensuring could utilization or his talents and skills.

Graham (1974) ${ }^{[9]}$ defines performance appraisal as the judgment of an employee's performance in his job based on other considerations than productivity alone. It is a planned and systematic method of obtaining analyzing and interpreting information about an employee or group of employees so as to evaluate their performance and create the right environment for failure improvement.

Every organization expects its employees and managers to put in maximum performance towards the actualization of very high productivity and performance in the modern complex business environment. As a necessary consequence of this need most organizations carry out periodic review and appraisal of the performance of the employees so as to determine their relative and continued usefulness in meeting organizational objectives

\subsubsection{Purpose of Performance Evaluation}

The general purpose of any staff appraisal system is to improve the efficiency of the organization by ensuring that individuals within it are performing to the best of their ability and developing their potentials. Armstrong (1982) ${ }^{[8]}$ stated that performance evaluation is intend to:- Measure the extent to which an employee is deserving of salary increase as compared to his peers.- Plan and follow up training and development programs that is identifying training needs and validating training method etc.-

Ubeku $(1983)^{[10]}$ pointed out the purpose of performance evaluation or appraisal thus: Performance appraisal will develop the strength and weakness of the employee and on the basis of this appropriate remedial action such training can be undertaken. The employees performance on the job where systematically analyzed will determine how they should be rewarded in terms of money or by promotion. A good appraisal scheme is fundamental to the management of people in any organization and that must not be ignored. Not only are we dealing with nature of individual human being who make up the organization. We must also recognize that the success of the organization itself depends largely on a good appraisal system. With good appraised system, those who contribute more will be adequately rewarded and the right types of people are likely to be promoted into position of higher responsibility.

\section{THEORETICAL REVIEW}

The concept of performance management is theoretically under-pined on the theory of motivation. There are several motivational theories as outlined below:

\subsection{Motivation Theories and Need of Paid Employees}

One of the basic problems in any organization is how to motivate people to work. In modern society, it is not an easy task since many people derive only slight personal satisfaction from their jobs and enjoy little sense of accomplishment or creativity. It is pertinent to attempt various definition of motivation so as to put the subject topic in the right perspective.

Cole $(1993)^{[11]}$ posited that motivation is a process in which people choose between alternative forms of behavior in order to achieve personnel goals. 
Need of Paid Employee: Over time, researches have revealed human needs as varying with the level of development in the society and the individuals that make it up. In Abraham Maslow's motivation theory (1943), the hierarchy of human needs was categorized into five as follows:-

- Physiological needs: Which covers such things as food, water and air? These are basic substance items whose quantity and quality have profound implications for survival and productivity.

- Safety needs: This seeks protection for the person from harm or fear of any kind, the loss of life, property, job, assets, capabilities position etc.

- Social need: This is where individual seek to express himself or herself in a group situation and then establish some form of relevance. It bothers on such things as friendship and team work.

- Self-esteem needs: This is whereby the individual accepts, that he / she has value it is an appreciation of self-worth and identity.

- Self-actualization needs tops the hierarchy, as the individual seeks fulfillment of potential and personal growth.

Quality and competitiveness by Ivancerich et al, (1994) ${ }^{[12]}$, the authors laid a parallel between Maslow hierarchy of human needs and the workplace as follows:-

- Adequate salary (physiological)

- Guaranteed employment, health benefits and retirement plans(safety)

- Group membership (social)

- Promotion or recognition (self-esteem)

- Increased participation in work decisions (self-actualization).

Employees that fall in these categories must be identified throughout the organization and policies should be fashioned out to support their needs. Obviously as people advance in organization, their particular needs changes and where it is imperative to retain specific talents, the organization needs to act decisively. This underlines the critical role or career plan in Human Resources Management. A proper plan will give an indication of where any two individual of average and exceptional performance will be in a couple of years.

However, despite the novelty of Maslow's theory in explaining what motivates an individual, the model has been vehemently criticized for its theoretical nature, since it lacks empirical evidence to support its conclusion that there is hierarchy of workers needs and that it is universally five. For instance, Lawler (1973) ${ }^{[13]}$, after reviewing the researches that has been carried out by themselves and others suggest that these studies offer little support for the view that the needs of workers in organization are arranged in a multi-level hierarchy.

Another very important inherent deficiency in Maslow's theory is the fact that, it is unable to explain in terms of age, race, education qualification and size of the organization in which the employee work; all of which may influence the importance attached to the various needs was pointed out that one fallacy in Maslow's model for workers aspiration as guide to behavior lies in its inherent static premise. Some research studies have established that workers in USA place more importance on Money, Japan, on respect and power, Latin America, array of needs; respect, job status and a good personal life.

\section{Methodology}

The paper adopted a singular source of data collection. The secondary source of data generation, which include the use of textbooks written by different authors on the subject matter, journals, magazines, information from the internet and other published and unpublished materials relevant to work. The data was analyzed using the content analysis approach. This is because of its major dependence on the secondary source data.

\section{CONCLUSiON}

The challenges of Human Management in commercial banks in Nigeria are multifaceted and multidimensional ranging from target setting, co-operate value ethics, recruitment, remuneration training reward/ recognition to retention. 
The bottom line is the ability of a bank to retain its staff especially the good ones. Usually when competitors approach them, they go for the best and the next in rank will only remain as long as no attractive offer comes his or her way.

"Assets make things possible, people make things happen". Employee's attitudes and job satisfaction have direct bearing upon the organizational health and effectiveness. As such, personnel in or organization, are considered to be the back-bone of the organization. Maximum attention must be paid towards the attitude and job satisfaction of the employees by any organization rest on the effective management of human psychology and behavior.

\section{RECOMMENDATIONS}

Having discussed the role of Human Resources its impacts and problems in the organization, the following measures are suggested to improve on the effective management of Human Resources in the organization as a strategy for corporate survival.

- For a more effective recruitment, selection and placement it is suggested that the organization should endeavor to advertise for any vacant position, thus broadening the area of selection and giving applicants with relevant qualification the opportunity to apply.

- This should be followed by a standardized aptitude test and formal interview with a view employing the best candidate for the job.

- One method of doing this is by making provision for advancement, promotion to deserving employees which economically means an increase in allowance. In addition housing loans, car loans etc should be given to qualified staff as and when due without difficulties.

- Also, the organization should make it clear to employees that working hard will lead to higher performance and that performance would lead to higher rewards which satisfy these needs.

\section{REFERENCES}

[1] Scott Clothier, Spiegel (1977)- Personnel Management - Principles, Practices and Point of view, $11^{\text {th }}$ Edition, Tata McGraw Hill, New Delhi.

[2] Northcott, J., and the PSI research Team. (1991). "Britain in 2010", Policy Studies Institute

[3] Wendell L. French (2006) Human Resources Management, $6^{\text {th }}$ edition, Houghton Mifflin.

[4] Flippo, E.B. (1984). Personnel Management. (6th Ed.) New York: McGraw Hill Book Co.

[5] Noe Raymond, Hollenbeck John, Gerhart, Barry, and Wright Patrick(2011): Human Resource Management, 4th Ed. McGraw-Hill, Irwin, New York.

[6] Ogundele, B. (1983): "Corporate Objective and Self Development" Management in Nigeria, Volume 19 Nos. $11 \& 12$

[7] Osukunle, B. (2002): "Human Capital Challenges in Banking Industry in Nigeria" A Paper Presented To the Graduating Mba Student of Oau Ile- Ife Monitor Newspaper $29^{\text {th }} \& 30^{\text {th }}$ January, 2002 Volumes $1 \& 2$

[8] Armstrong, M. (1984): Handbook on Personal Management Practice; Second Edition, London, Kogan Publishers.

[9] Graham T. (1974): Human Resources Management: Plymouth, Mcdonalds

[10] Ubeku, A. (1983): Industrial Relations in Developing Countries. A Case Study of Nigeria. London Macmillan Press

[11] Cole, G. (1993): Personnel Management Theory and Practice London, Dp Publishers Ltd

[12] John M. Ivancevich, Peter Lorenzi, Steven J. Skinner \& Philip B. Crosby, "Management Quality and Competitiveness", 1994 Burr Ridge, Illinois, Irwin Amsterdam, Addison-Wesley Publishing Group ISBN 0 256124531

[13] Lawler, E (1973): Motivation in Work Organization. California Books Cole Publishing Company.

Citation: Dr. Cross Ogohi Daniel. “ Human Resource Management and its Effects on the Performance of Nigerian Commercial Banks" International Journal of Managerial Studies and Research (IJMSR), vol 6, no. 9, 2018, pp. 38-43. doi: http://dx.doi.org/10.20431/2349-0349.0609004.

Copyright: (C) 2018 Authors. This is an open-access article distributed under the terms of the Creative Commons Attribution License, which permits unrestricted use, distribution, and reproduction in any medium, provided the original author and source are credited. 